Journal of Information System, Informatics and Computing

Website/URL: http://journal.stmikjayakarta.ac.id/index.php/jisicom

Email: jisicom@stmikjayakarta.ac.id, jisicom2017@gmail.com

\title{
SISTEM INFORMASI ADMINISTRASI \\ PERSURATAN BERBASIS WEB \\ PADA BIRO KEPEGAWAIAN DAN ORGANISASI BADAN NARKOTIKA NASIONAL
}

\author{
Widyawati $^{1}$, Agus Sulistyanto ${ }^{2}$, Anton Z. Sianipar ${ }^{3}$ \\ Program Studi Sistem Informasi ${ }^{1,2,3}$ \\ Sekolah Tinggi Manajemen Informatika dan Komputer Jayakarta \\ 19567001@ stmik.jayakarta.ac.id ${ }^{1}$, agus.sulistyanto@ gmail.com ${ }^{2}$, \\ umum.jakarta2@gmail.com ${ }^{3}$
}

Received: February 07, 2021. Revised: March 08, 2021. Accepted: April 25, 2021. Published: June 20, 2021. Issue Period: Vol.5 No.1 (2021), Pp.174-183

\begin{abstract}
Abstrak: Pengelolaan persuratan merupakan hal yang sangat penting dalam sebuah organisasi. Sistem pengelolaan persuratan yang saat ini berjalan di Biro Kepegawaian dan Organisasi Sekretariat Utama Badan Narkotika Nasional dirasakan masih mempunyai berbagai kekurangan diantaranya adalah aplikasi persuratan hanya bisa dijalankan oleh administrator. Sementara, pegawai lain yang berkepentingan terhadap surat tersebut tidak bisa mengaksesnya. Penyampaian disposisi surat masih dilakukan secara fisik dan menjadi penghalang apabila penerima surat tidak berada di tempat. Hal ini menyebabkan pemborosan waktu dan media. Peneliti tertarik untuk membuat sebuah sistem pengeloaan persuratan yang mampu menyelesaikan permasalahan menggunakan metode UML (Unified Modelling Language) dan pendekatan pengembangan perangkat lunak menggunakan metode RAD (Rapid Application Development) sehingga diperoleh sebuah aplikasi yang diharapkan mampu meringkas berbagai proses administrasi persuratan yang sebelumnya kurang efektif menjadi sebuah sistem yang bisa mempercepat proses distribusi surat secara berjenjang hingga pembuatan laporan secara real time.
\end{abstract}

Kata kunci: Surat, pengembangan, aplikasi

\begin{abstract}
Correspondence management is very important in an organization. The correspondence management system is currently running in the Biro Kepegawaian dan Organisasi Sekretariat Utama Badan Narkotika Nasional that is felt to have various shortcomings, which is the correspondence application can only be run by an administrator. Meanwhile, other employees with an interest in the letter cannot access it. The delivery of letter dispositions is still carried out physically and becomes a barrier if the recipient of the letter is not present. This results in a waste of time and media. Researchers are interested in creating a correspondence management system that is able to solve problems using the UML (Unified Modeling Language) method and the RAD (Rapid Application Development) process model is used in developing software. This application is expected to be able to summarize the
\end{abstract}

DOI: $10.52362 /$ jisicom.v5i1.380

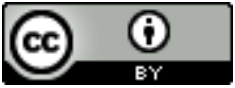

Ciptaan disebarluaskan di bawah Lisensi Creative Commons Atribusi 4.0 Internasional. 
Journal of Information System, Informatics and Computing

Website/URL: http://journal.stmikjayakarta.ac.id/index.php/jisicom

Email: jisicom@stmikjayakarta.ac.id, jisicom2017@gmail.com

various administrative processes of correspondence that were previously ineffective so that it can speed up the process of distributing letters in stages to making reports in real time.

Keywords: letters, development, application

\section{PENDAhuluan}

1. Permasalahan

Surat adalah salah satu sarana penyampaian informasi formal yang dipakai oleh banyak perusahaan maupun instansi pemerintah. Kecepatan pengiriman surat menjadi hal yang sangat diperlukan. Sayangnya, banyak perusahaan maupun instansi yang masih menggunakan surat fisik sebagai sarana penyampaian informasi.

Pada Biro Kepegawaian dan Organisasi Sekretariat Utama Badan Narkotika Nasional, pengiriman perintah dalam bentuk surat masih ditemukan menggunakan sistem manual yaitu berkas secara fisik dikirimkan ke pegawai yang dituju. Hal ini menyebabkan pemborosan dari segi waktu, media dan tenaga. Selain itu pengiriman fisik ini mempunyai berbagai kendala diantaranya tidak bisa dilakukan pemantauan secara langsung oleh pimpinan. Selain dikirim secara fisik berkas digital juga dikirim melalui email. Di Biro Kepegawaian dan Organisasi sendiri sudah tersedia sistem persuratan, namun belum bisa memenuhi kebutuhan organisasi secara cepat, terutama saat pencarian surat.

2. Teori terkait

Administrasi secara luas adalah serangkaian kegiatan yang dilakukan sekelompok orang dalam sebuah kerjasama untuk mencapai tujuan tertentu (Hanafi,2018) [1]. Menurut Dra. RR. Ponco Dewi Karyaningsih, M.M. (2018) dalam bukunya Korespondensi Surat Bisnis dan Dinas mengatakan bahwa: "secara umum surat adalah suatu sarana untuk menyampaikan informasi atau pernyataan secara tertulis kepada pihak lain baik atas nama pribadi (sendiri) ataupun karena kedinasan. Surat juga merupakan wakil resmi dari yang mengirim untuk membicarakan masalah yang dihadapi. Secara singkat dapat diketemukan bahwa surat adalah alat komunikasi penting dalam tata kerja tata usaha. Apabila terjadi hubungan surat menyurat secara terus menerus dan berkesinambungan, maka kegiatan ini disebut surat menyurat atau lazimnya korespondensi.[2]

\section{MATERI DAN METODE}

1. Kerangka pemikiran

Pengelolaan persuratan sebaiknya mampu menyajikan data surat masuk dan disposisi elektronik secara real time sehingga mampu meningkatkan kinerja pegawai dan mempercepat tecapainya tujuan organisasi. Peneliti memberikan usulan untuk membuat sistem informasi persuratan yang bisa diakses oleh seluruh pegawai berikut fasilitas pemberian disposisi langsung pada aplikasi yang diharapkan akan mampu mengatasi masalah yang terjadi saat ini agar bisa meningkatkan efektivitas dalam bekerja baik bagi pegawai maupun pimpinan dalam mencapai tujuan sesuai tugas pokok dan fungsi organisasi

2. Teori pendukung

Agar informasi bisa diterima oleh pemakai dengan lancar, kemudahan akses terhadap informasi harus terjamin. Oleh karena itu, pihak-pihak yang berkompeten dengan informasi biasanya dilengkapi dengan komputer pribadi (PC) yang tersambung dengan komputer server yang menyimpan data untuk memudahkan pengaksesan informasi. Suatu sistem pada dasarnya adalah sekelompok unsur yang erat hubungannya satu dengan yang lain, yang berfungsi bersama-sama untuk mencapai tujuan tertentu (Sutabri, 2012) [3]. Model umum sebuah sistem adalah input, proses dan output.

UML (Unified Modeling Language) adalah sebuah bahasa yang berdasarkan grafik/gambar untuk memvisualisasi, menspesifikasikan, membangun, dan pendokumentasian dari sebuah sistem pengembangan software berbasis OO (Object-Oriented). UML sendiri juga memberikan standar penulisan sebuah sistem blue

DOI: $10.52362 /$ jisicom.v5i1.380

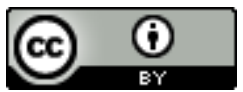

Ciptaan disebarluaskan di bawah Lisensi Creative Commons Atribusi 4.0 Internasional. 


\section{Journal of Information System, Informatics and Computing}

Website/URL: http://journal.stmikjayakarta.ac.id/index.php/jisicom

Email: jisicom@stmikjayakarta.ac.id, jisicom2017@gmail.com

print, yang meliputi konsep bisnis proses, penulisan kelas-kelas dalam bahasa program yang spesifik, skema database, dan komponen-komponen yang diperlukan dalam sistem software. (Mubarak, 2019) [4].

3. Pembahasan metode

Metode penelitian yang digunakan oleh peneliti yaitu observasi langsung pada tempat penelitian. Selain itu peneliti juga melakukan wawancara terhadap pengguna sistem dan yang terakhir adalah studi literature / kepustakaan untuk melengkapi bahan penelitian yang dilakukan dengan mengumpulkan sumber baik secara offline maupun online.

Rapid Application Development (RAD) digunakan dalam metode pengembangan sistem yang meliputi proses desain sistem, coding, implementasi, analisis sistem.

Hasil analisis peneliti terhadap sistem yang sudah dipelajari adalah ditawarkankannya sebuah aplikasi pengeloaan persurata berbasis web yang mampu memenuhi kebutuhan e-office bagi pegawai dan pimpinan. Berikut ini skenario proses penerapan sistem:

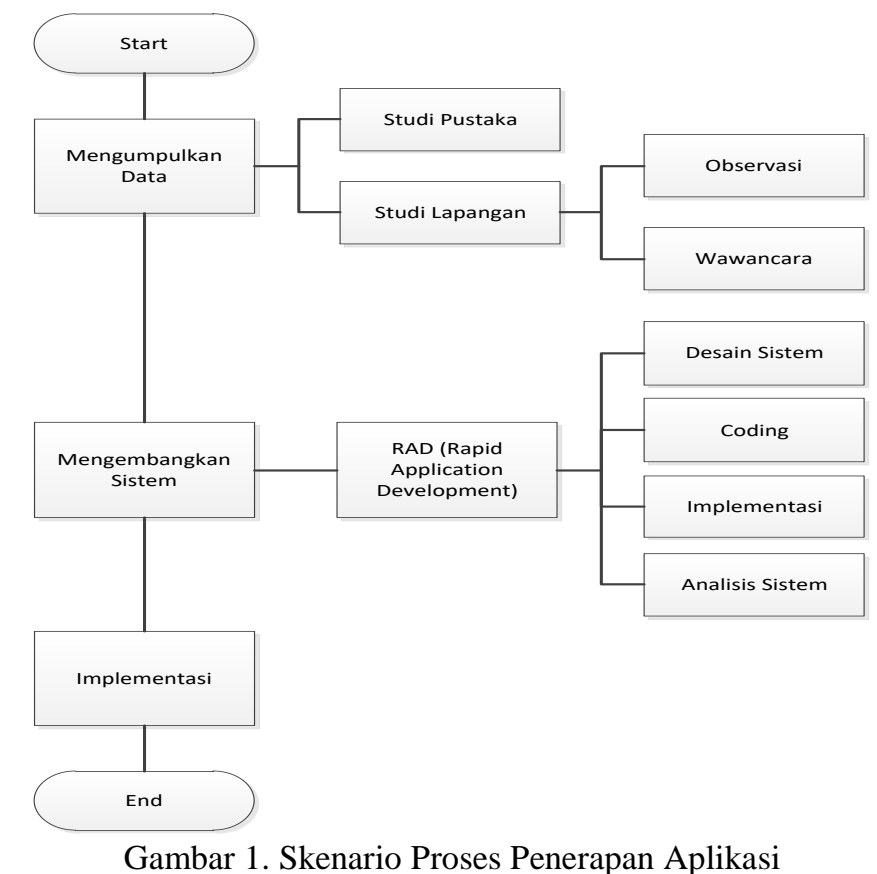

\section{III.PEMBAHASAN DAN HASIL}

1. Analisis sistem

Diagram use case digunakan untuk menggambarkan proses yang terjadi antara user dalam hal ini pegawai dan pimpinan serta administrator pada Biro Kepegawaian dengan sistem yang akan dibuat. Rancangan usescase diagram yang diusulkan adalah

DOI: $10.52362 /$ jisicom.v5i1.380

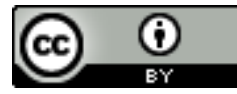

Ciptaan disebarluaskan di bawah Lisensi Creative Commons Atribusi 4.0 Internasional. 
e-ISSN : 2597-3673 (Online) , p-ISSN : 2579-5201 (Printed)

Vol.5 No.1, Juni 2021

Journal of Information System, Informatics and Computing

Website/URL: http://journal.stmikjayakarta.ac.id/index.php/jisicom

Email: jisicom@stmikjayakarta.ac.id, jisicom2017@gmail.com

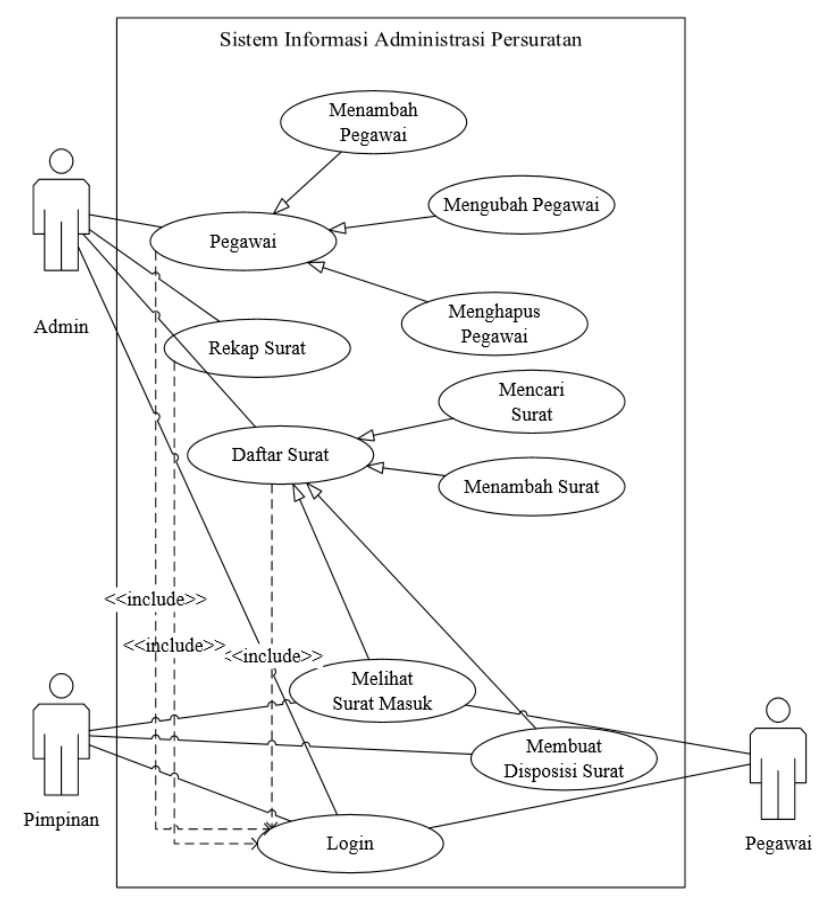

Gambar 2. Use Case Diagram

Diagram proses activity yang dihasilkan pada pembuatan sistem adalah sebagai berikaut:

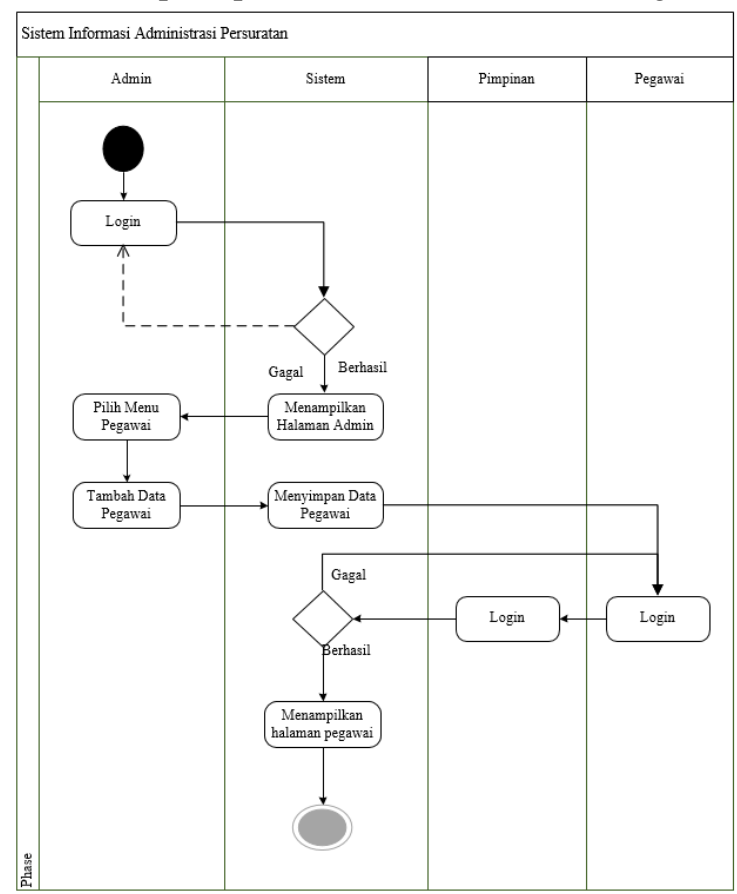

Gambar 3. Activity Diagram pada Menu Pegawai

DOI: $10.52362 /$ jisicom.v5i1.380

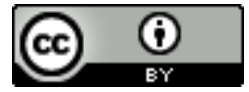

Ciptaan disebarluaskan di bawah Lisensi Creative Commons Atribusi 4.0 Internasional. 
e-ISSN : 2597-3673 (Online) , p-ISSN : 2579-5201 (Printed)

Vol.5 No.1, Juni 2021

Journal of Information System, Informatics and Computing

Website/URL: http://journal.stmikjayakarta.ac.id/index.php/jisicom

Email: jisicom@stmikjayakarta.ac.id, jisicom2017@gmail.com

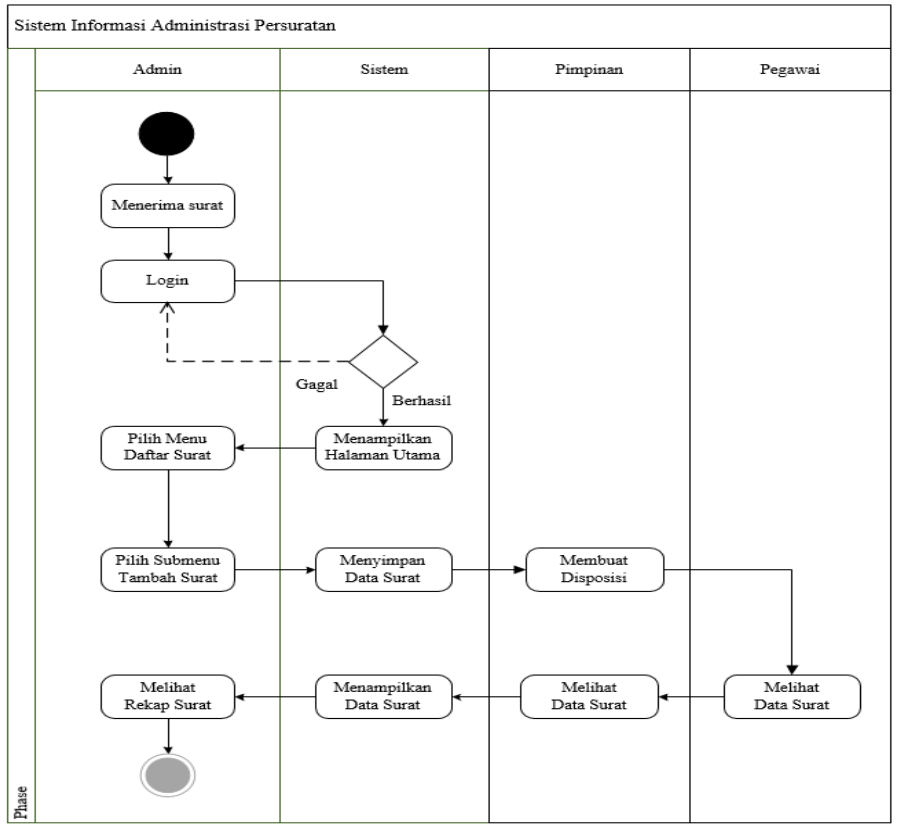

Gambar 4. Activity Diagram pada Menu Surat

Class Diagram dapat digambarkan sebagai berikut:

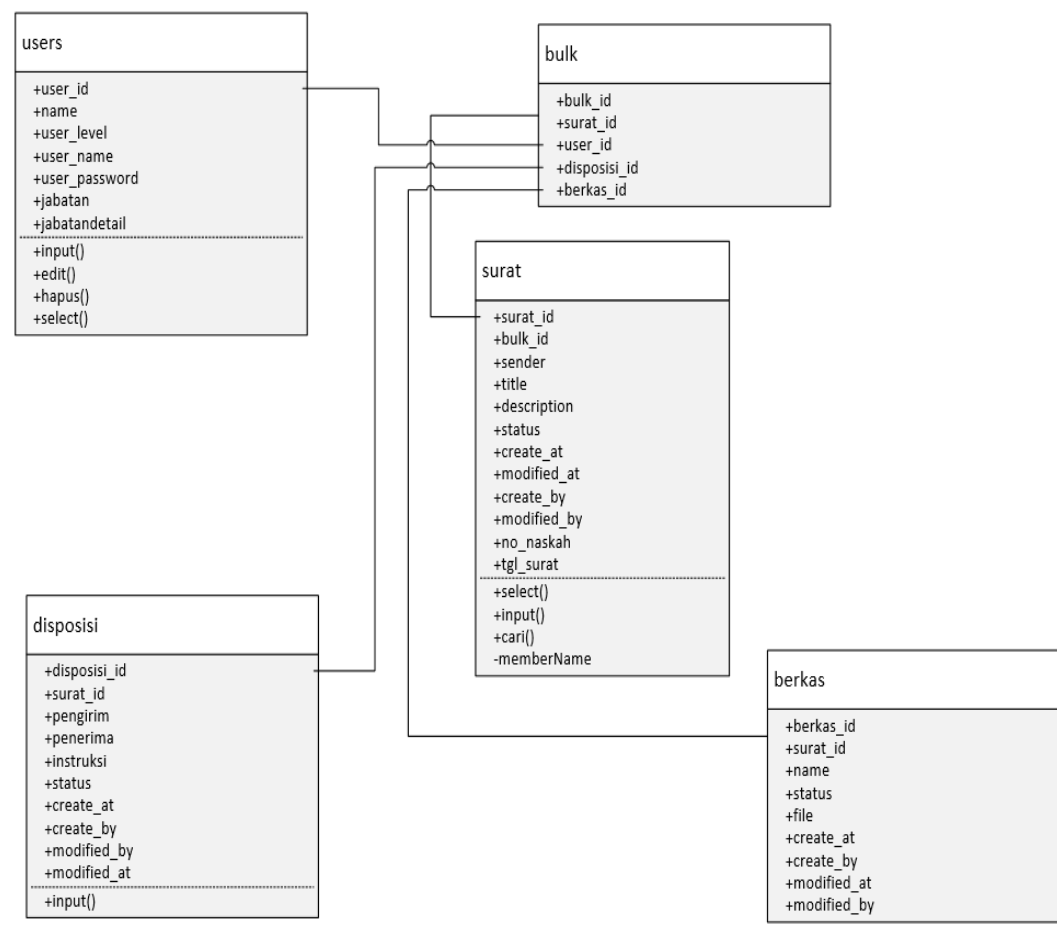

Gambar 5. Class Diagram Sistem

DOI: $10.52362 /$ jisicom.v5i1.380

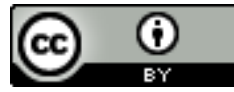

Ciptaan disebarluaskan di bawah Lisensi Creative Commons Atribusi 4.0 Internasional. 
Journal of Information System, Informatics and Computing

Website/URL: http://journal.stmikjayakarta.ac.id/index.php/jisicom

Email: jisicom@stmikjayakarta.ac.id, jisicom2017@gmail.com

2. Proses pemodelan

Menggunakan diagram Hirarki Input Proses Output (HIPO) berfungsi untuk memperlihatkan jenjang atau hirarki dari suatu sistem. Diagram HIPO dari Sistem Informasi Administrasi Persuratan digambarkan sebagai berikut :

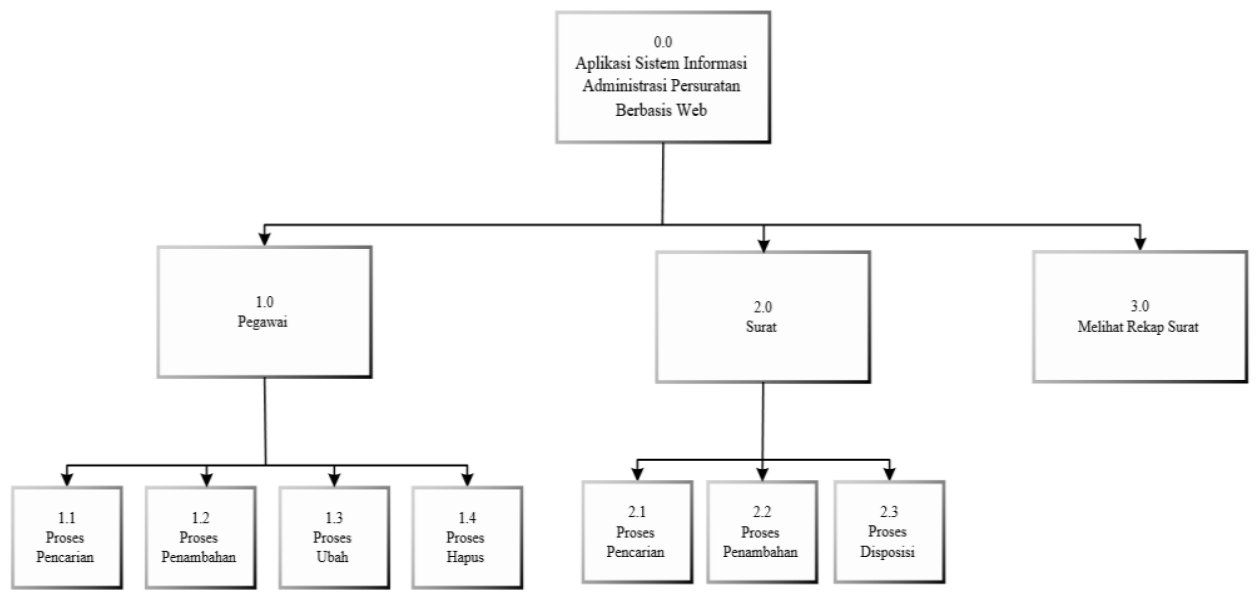

Gambar 6. Diagram HIPO

3. Model pengujian dan hasil pengujian

Pengujian atau testing merupakan tahapan terakhir dalam proses pembuatan sebuah aplikasi. Pengujian yang lakukan untuk menguji aplikasi ini adalah dengan menggunakan metode Black Box Testing. Pengujian dengan metode pada aplikasi Sistem Informasi Administrasi Persuratan dilakukan dengan cara memberikan input pada program. Input tersebut akan di proses sesuai dengan fungsinya untuk melihat apakah program dapat menghasilkan output yang sesuai dengan yang diharapkan.

Dari hasil pengujian terseBut diperoleh bahwa aplikasi yang disusulkan sudah memenuhi kebutuhan organisasi dengan flowchart aplikasi sebagai berikut:

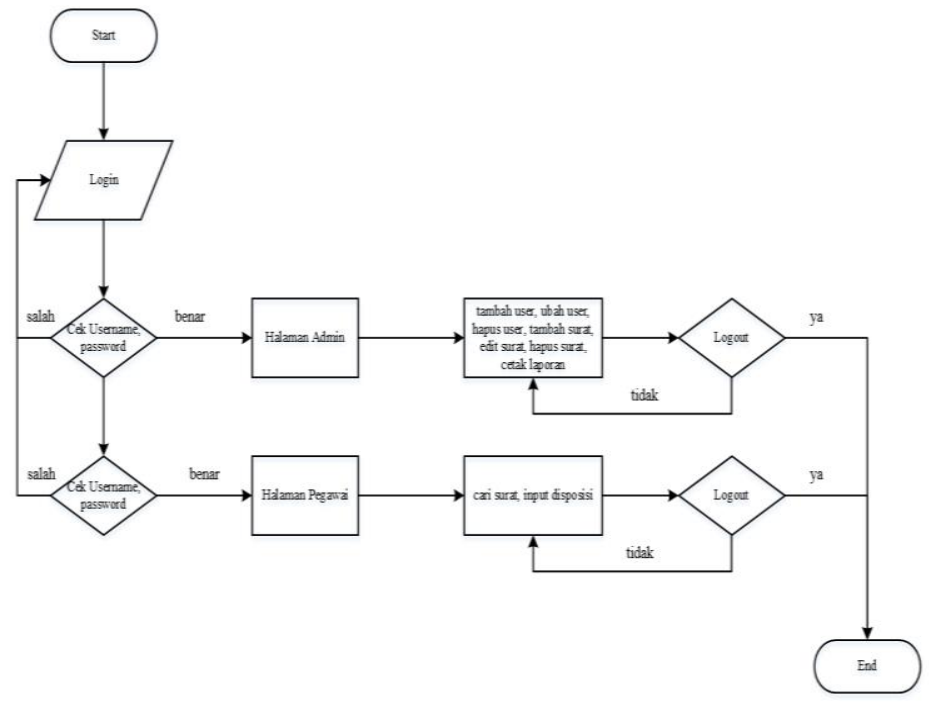

Gambar 7. Flowchart Diagram

DOI: $10.52362 /$ jisicom.v5i1.380

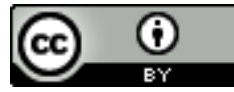

Ciptaan disebarluaskan di bawah Lisensi Creative Commons Atribusi 4.0 Internasional. 
e-ISSN : 2597-3673 (Online) , p-ISSN : 2579-5201 (Printed)

Vol.5 No.1, Juni 2021

Journal of Information System, Informatics and Computing

Website/URL: http://journal.stmikjayakarta.ac.id/index.php/jisicom

Email: jisicom@stmikjayakarta.ac.id, jisicom2017@gmail.com

Berikut ini adalah tampilan aplikasi pada beberapa menu dan sub menu yang tersedia pada sistem yang dirancang oleh peneliti.
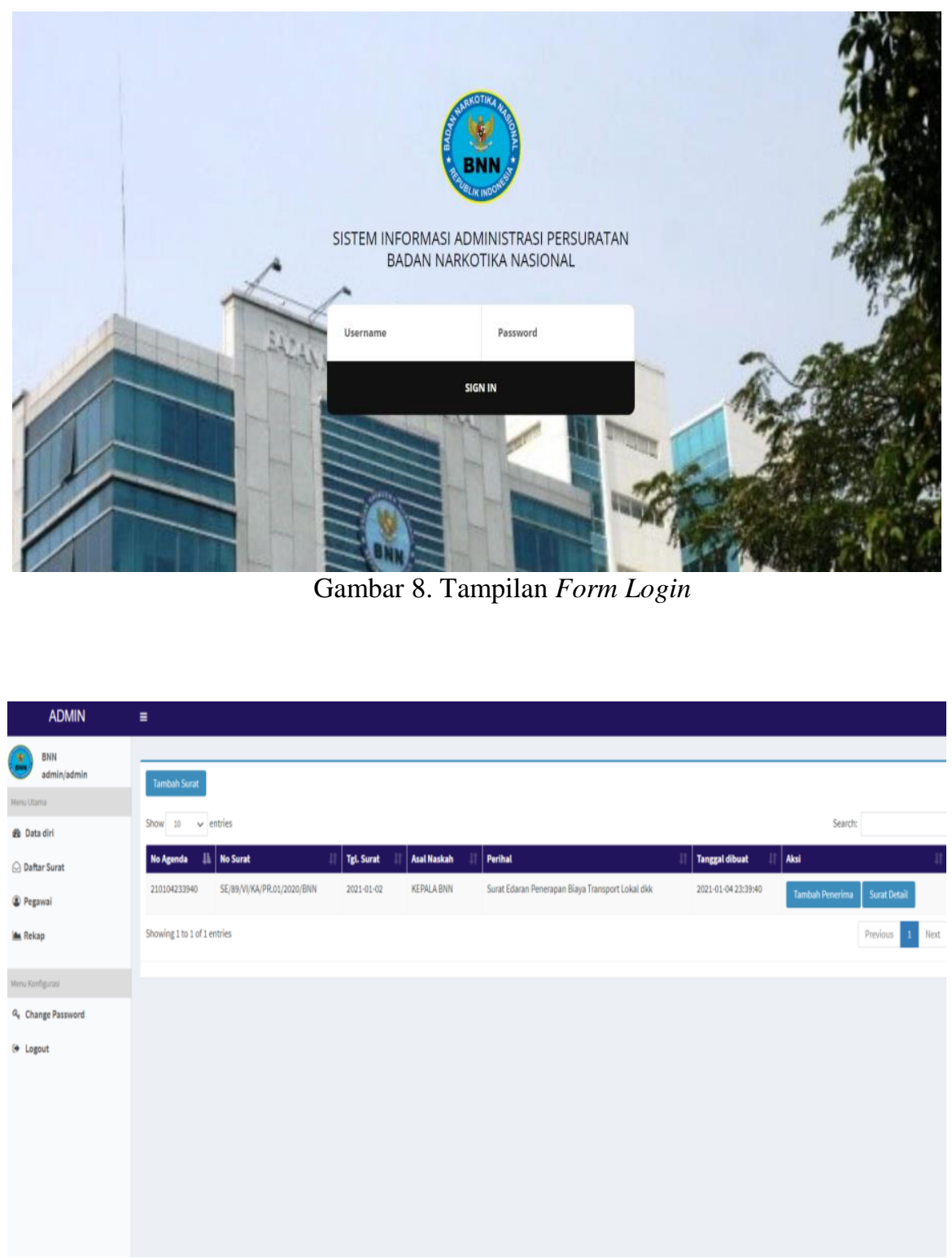

Gambar 9. Tampilan Menu Surat

DOI: $10.52362 /$ jisicom.v5i1.380

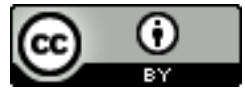

Ciptaan disebarluaskan di bawah Lisensi Creative Commons Atribusi 4.0 Internasional. 
Journal of Information System, Informatics and Computing

Website/URL: http://journal.stmikjayakarta.ac.id/index.php/jisicom

Email: jisicom@stmikjayakarta.ac.id,jisicom2017@gmail.com
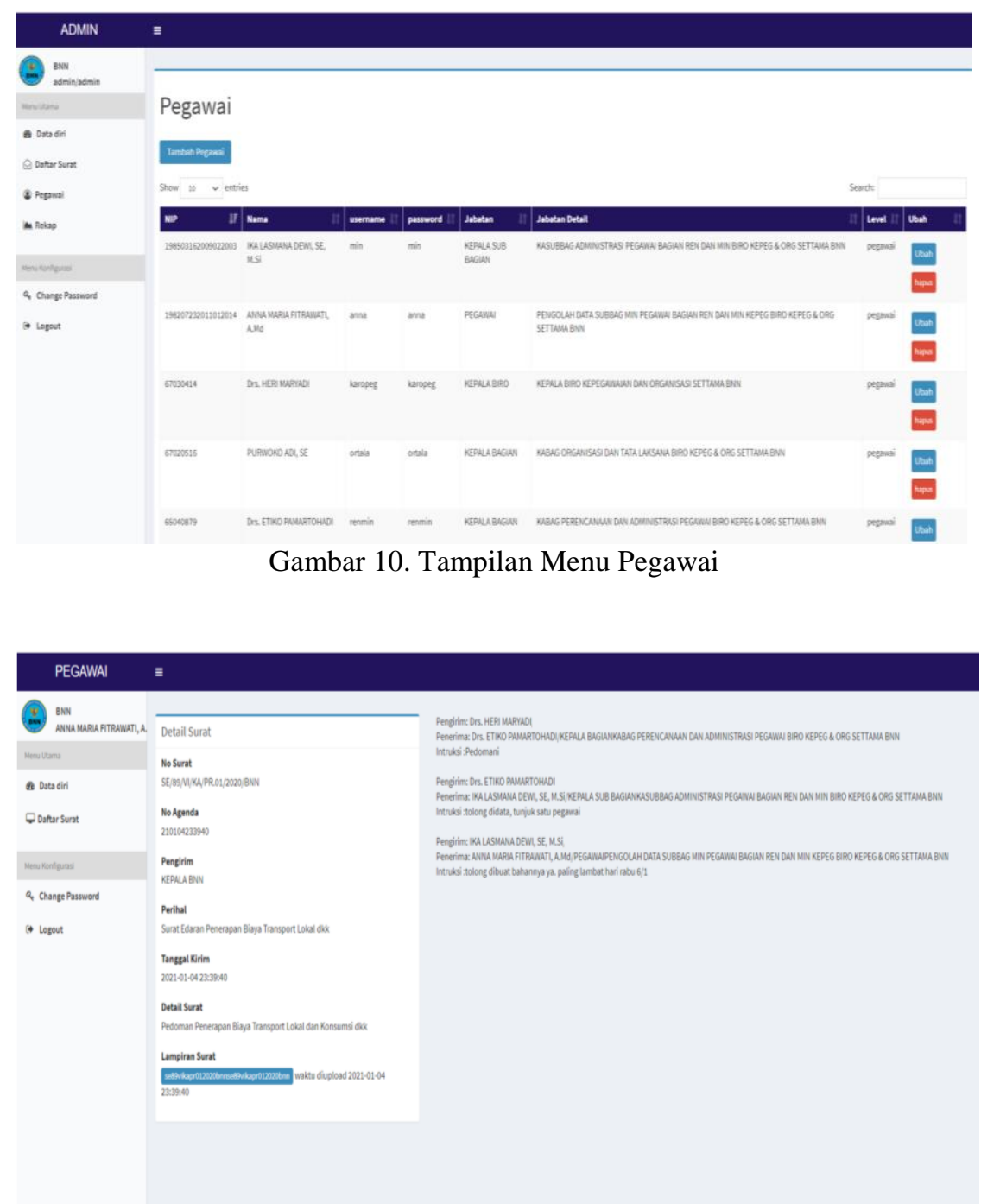

Gambar 11. Tampilan Disposisi Surat

\section{KESIMPULAN}

Proses perancangan yang digunakan pada penelitian ini menggunakan teknik UML (Unified Modeling Language). Sedangkan pengembangan sistem digunakan metode RAD (Rapid Aplication Development) tepat diterapkan pada tema penelitian kali ini. Metode ini mempelajari kebutuhan di lapangan secara langsung beserta batasan-batasan yang selanjutnya ditentukan dengan pasti, sehingga pembuatan sistem pun dapat dikerjakan dalam waktu yang relatif singkat.

Dengan adanya sistem informasi administrasi persuratan ini dapat membantu Biro Kepegawaian dan Organisasi dalam proses pengadministrasian persuratan dan juga mampu memberikan fasilitas kepada pimpinan dan pegawai untuk melihat dan mendapatkan informasi yang dapat diakses kapanpun dan dimanapun.

DOI: $10.52362 /$ jisicom.v5i1.380

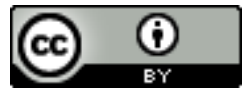

Ciptaan disebarluaskan di bawah Lisensi Creative Commons Atribusi 4.0 Internasional. 
Journal of Information System, Informatics and Computing

\section{REFERENSI}

[1] Hanafi, M. (2018). Administrasi Perkantoran. Indomedia Pustaka.

[2] Karyaningsih, P. D. (2018). Korespondensi Surat Bisnis dan Dinas. In Korespondensi Surat Bisnis dan Dinas. http://sipeg.unj.ac.id/repository/upload/buku/148_korespondensi.pdf

[3] Sutabri, T. (2012). Analisis Sistem Informasi. In Analisa Sistem Informasi.

[4] Mubarak, A. (2019). Rancang Bangun Aplikasi Web Sekolah Menggunakan UML (Unified Modeling Language) Dan Bahasa Pemrograman PHP (Php Hypertext Preprocessor) Berorientasi Objek. JIKO (Jurnal Informatika Dan Komputer). https://doi.org/10.33387/jiko.v2i1.1052

[5] Nur Aini dkk "Pembangunan Sistem Informasi Perpustakaan Berbasis Web menggunakan Metode Rapid Application Development (RAD) (Studi pada : SMK Negeri 11 Malang)"

[6] Nurul Alifah Rahmawat dkk "Analisis dan perancangan desain sistem informasi perpustakaan sekolah berdasarkan kebutuhan sistem"

[7] Muhammad Husni Rifqo, dkk Jurnal “Implementasi Algoritma Backtracking Dalam sistem informasi perpustakaan untuk pencarian judul buku (studi kasus unit pelayanan terpadu perpustakaan universitas muhammadiyah bengkulu)"

[8] Yayasan Pengembangan Perpustakaan Indonesia, Pengertian, Tujuan dan Fungsi Perpustakaan Keliling,diakses melalui situs: (http://www.pustakaindonesia.org/2011/04/09/pengertian-tujuan-dan-fungsi-perpustakaankeliling/) pada Tanggal 26 Oktober 2020.

[9] Anis Rohmadi, Verdi Yasin (2020) “Desain Dan Penerapan Website Tata Kelola Percetakan Pada CV Apicdesign Kreasindo Jakarta Dengan Metode Prototyping", Journal of Information System, Informatics and Computing. http://journal.stmikjayakarta.ac.id/index.php/jisicom/article/view/210 E-ISSN: 2597-3673 (Online), P-ISSN: 2579-5201 (Print) Vol. 4 No.1, June 22, 2020. Pp.70-85

[10] Septian Cahyadi, Verdi Yasin, Mohammad Narji, Anton Zulkarnain Sianipar (2020) "Perancangan Sistem Informasi Pengiriman Dan Penerimaan Soal Ujian Berbasis Web ( Studi Kasus: Fakultas Komputer Universitas Bung Karno)", Journal of Information System, Informatics and Computing. http://journal.stmikjayakarta.ac.id/index.php/jisicom/article/view/199 E-ISSN: 2597-3673 (Online), P-ISSN: 2579-5201 (Print) Vol. 4 No.1, June 22, 2020. Pp.1-16

[11] Ifan Junaedi, Ndaru Nuswantari, Verdi Yasin (2019) “Perancangan Dan Implementasi Algoritma C4.5 Untuk Data Mining Analisis Tingkat Risiko Kematian Neonatum Pada Bayi", Journal of Information System, Informatics and Computing. http://journal.stmikjayakarta.ac.id/index.php/jisicom/article/view/203 E-ISSN: 2597-3673 (Online), P-ISSN: $2579-5201$ (Print) Vol. 3 No.1, February 13, 2019. Pp.29-44.

[12] Verdi Yasin, Anindra Ramdhan Nugraha, Muhammad Zarlis, Ifan Junaedi (2018) "Smart System Of Fast Internet Access Development Using Backbone Network Method", Journal of Information System, Informatics and Computing. http://journal.stmikjayakarta.ac.id/index.php/jisicom/article/view/198 E-ISSN: 2597-3673 (Online), P-ISSN: $2579-5201$ (Print) Vol. 2 No. 2, December 31, 2018. Pp.26-34.

[13] Ito Riris Immasari, Verdi Yasin (2019) "Penggunaan Metode Analytic Hierarchy Process Untuk Menganalisis Faktor-Faktor Yang Mempengaruhi Pemilihan Calon Legislatif Di Dprd li Kota Tangerang”, Journal of Information System, Informatics and Computing. http://journal.stmikjayakarta.ac.id/index.php/iisicom/article/view/139 E-ISSN: 2597-3673 (Online), P-ISSN: 2579-5201 (Print) Vol. 3 No. 2, December 10, 2019. Pp.53-58.

[14] Verdi Yasin, Muhammad Zarlis, Tulus, Erna Budhiarti Nababan, Poltak Sihombing (2019) “Rancangan Miniatur Otomatisasi Bel Listrik Pada Gerbang Pintu Menggunakan Microkontroler Atmega8535", Journal of Information System, Informatics and Computing. http://journal.stmikjayakarta.ac.id/index.php/iisicom/article/view/68 E-ISSN: 2597-3673 (Online), P-ISSN: 2579-5201 (Print) Vol. 3 No. 1, February 13, 2019. Pp.13-20.

[15] Anggeri S. Nurjaman, Verdi Yasin (2020) “Konsep Desain Aplikasi Sistem Manajemen Kepegawaian Berbasis Web Pada PT. Bintang Komunikasi Utama ", Journal of Information System, Informatics and Computing.

DOI: $10.52362 /$ jisicom.v5i1.380

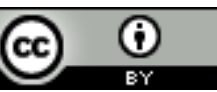

Ciptaan disebarluaskan di bawah Lisensi Creative Commons Atribusi 4.0 Internasional. 
e-ISSN : 2597-3673 (Online) , p-ISSN : 2579-5201 (Printed)

Vol.5 No.1, Juni 2021

Journal of Information System, Informatics and Computing

Website/URL: http://journal.stmikjayakarta.ac.id/index.php/jisicom

Email: jisicom@stmikjayakarta.ac.id, jisicom2017@gmail.com

http://journal.stmikjayakarta.ac.id/index.php/jisicom/article/view/363 E-ISSN: 2597-3673 (Online), P-ISSN: 2579-5201 (Print) Vol. 4 No. 2, December 28, 2020. Pp.143-174.

[16] Verdi Yasin, Azhar Ahmad Riza, Rumadi Hartawan (2017) “Pengembangan Aplikasi Pemulihan Layanan Bencana Sistem Informasi Peneriman Negara Bukan Pajak Online Di Lingkungan Kementerian Keuangan Republik Indonesia", Journal of Information System, Informatics and Computing.

http://journal.stmikjayakarta.ac.id/index.php/jisicom/article/view/4 E-ISSN: 2597-3673 (Online), P-ISSN: 2579-5201 (Print) Vol. 1 No. 1, September 20, 2017. Pp.33-56.

DOI: $10.52362 /$ jisicom.v5i1.380

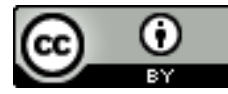

Ciptaan disebarluaskan di bawah Lisensi Creative Commons Atribusi 4.0 Internasional. 